fashion or new methods of stimulation?]. Rossiyskiy zhurnal menedzhmenta [Russian management journal] (electronic publication). Available at: https://cyberleninka.ru/article/n/geymifikatsiy a-i-avtomatizatsiya-kpi-ocherednayaupravlencheskaya-moda-ili-novye-metodystimulirovaniya (accessed 13 May 2019).

15 Kheyzinga Y. (2017) Homo Ludens. Chelovek igrayushchiy. Opyt opredeleniya igrovogo elementa kul'tury [Man playing. Experience in defining the game element of culture]. Sankt-Peterburg: ID Ivana Limbakha. (in Russian)

16 Shaposhnikova A.A. (2016) Geymifikatsiya kak novaya model' professional'nogo razvitiya personala [Gamification as a new model of personnel professional development]. Vestnik nauki $i$ obrazovaniya [Journal of science and education] (electronic publication). Available at:

https://cyberleninka.ru/article/n/geymifikatsiy a-kak-novaya-model-professionalnogorazvitiya-personala (accessed 17 May 2019).
17
Shtonda
A.S.
(2017)

Geymifikatsiya kak instrument uspeshnogo upravleniya personalom [Gamification as a tool for successful personnel management]. Biznes-obrazovanie $v$ ekonomike znaniy [Business education in knowledge economy] (electronic publication). Available at: https://cyberleninka.ru/article/n/geymifikatsiy a-kak-instrument-uspeshnogo-upravleniyapersonalom (accessed 19 May 2019).

18 Dy`kan` V.L., Borovy`k Yu.T., Polyakova O.M., Utkina Yu.M. (2011) Zabezpechennya konkurentospromozhnosti pidpry yemstv [Ensuring the competitiveness of enterprises]. UkrDAZT. (in Ukrainian)

19 Panchenko S.V., Dy`kan` V.L., Shramenko O.V., Polyakova O.M., Utkina Yu.M. (2016) Teorety`chni osnovy` organizaciyi pidpry`yemny`cz`koyi diyal'nosti [Theoretical bases of the organization of business activity]. Pidpry`yemny ‘ztvo [Business]. Xarkiv: UkrDUZT. (in Ukrainian)

20 Panchenko S.V., Dy`kan` V.L., Shramenko O.V., Polyakova O.M., Utkina Yu.M. (2016) Realizaciya pidpry`yemny`cz `oyi diyal`nosti u suchasny`x ry`nkovy`x umovax [Implementation of entrepreneurial activity in modern market conditions]. Pidpry`yemny cztvo [Business]. Xarkiv: UkrDUZT. (in Ukrainian)

21 Panchenko S.V., Dy`kan` V.L., Volovel`s`ka I.V. ta in. (2017) Upravlinnya biznesom [Business management]. Xarkiv: UkrDUZT. (in Ukrainian) 


\title{
ТЕОРЕТИЧНІ ПІДХОДИ ДО РОЗУМІННЯ СУТНОСТІ МАРКЕТИНГОВОЇ ТОВАРНОЇ ПОЛІТИКИ ПІДПРИЕМСТВА
}

\author{
Кузьминчук Н. В., д.е.н., професор, \\ Куценко Т. М., к.е.н., доцент, \\ Терованесова О. Ю., к.е.н. (ХНУ ім. В. Н. Каразіна)
}

\begin{abstract}
Сформовано теоретичний базис ефективної маркетингової товарної політики промислового підприємства, зокрема, визначено сутнісне розуміння поняття «маркетингова товарна політика». Обгрунтовано головну мету, иілі та завдання маркетингової товарної політики промислового підприємства, щзо дозволяє виокремити основні напрямки ї̈ реалізації з метою досягнення стратегічних иілей, на основі наявних виробничих та ресурсних можливостей підприємства. Розкрито сутнісні характеристики основних напрямів маркетингової товарної політики та визначено інструменти їх реалізачії. Запропоновано при визначенні напрямів маркетингової товарної політики враховувати фактори зовнішнього та внутрішнього середовища, щзо визначають ичілі та завдання ії реалізації.

Ключові слова:маркетингова товарна політика, промислове підприємство, напрямки маркетингової товарної політики, фактори зовнішнього та внутрішнього середовища.
\end{abstract}

\section{ТЕОРЕТИЧЕСКИЕ ПОДХОДЫ К ПОНИМАНИЮ СУЩНОСТИ МАРКЕТИНГОВОЙ ТОВАРНОЙ ПОЛИТИКИ ПРЕДПРИЯТИЯ}

\author{
Кузьминчук Н. В., д.э.н., профессор, \\ Куценко Т. Н., к.э.н., доцент, \\ Терованесова А. Ю., к.э.н. (ХНУ им. В. Н. Каразина)
}

Сформирован теоретический базис эффективной маркетинговой товарной политики промышленного предприятия, в частности, определено сущностное понимание понятия «маркетинговая товарная политика». Обоснованно главную цель, цели и задачи маркетинговой товарной политики промышленного предприятия, что позволяет выделить основные направления ее реализащии с целью достижсения стратегических иелей, на основе имеющихся производственных и ресурсных возможностей предприятия. Раскрыты сущчностные характеристики основных направлений маркетинговой товарной политики и определены инструменты их реализаџии. Предложено при определении направлений маркетинговой товарной политики учитывать факторы внешней и внутренней среды, определяющие цели и задачи ее реализации.

Ключевые слова: маркетинговая товарная политика, промышленное предприятие, направления маркетинговой товарной политики, факторы внешней и внутренней среды.

(C) Кузьминчук Н.В.,

Куценко Т.М.,

Терованесова О.Ю.

Вісник економіки транспорту і промисловості № 66, 2019 


\title{
THEORETICAL APPROACHES FOR THE UNDERSTANDING OF THE NATURE OF THE MARKETING PRODUCTS POLICY OF THE ENTERPRISE
}

\author{
Kuzmynchuk N., Doctor of Economics, Professor, \\ Kutsenko T., PhD of Economics, Associate Professor, \\ Terovanesova O., PhD of Economics, (V. N. Karazin Kharkiv National University)
}

It is formed the theoretical basis of an effective marketing products policy of the industrial enterprise, in particular, the essential understanding of the concept of "marketing products policy" is determined. It is proved the main goal, goals and objectives of marketing products policy of the industrial enterprise which allows to single out the main directions of its realization in order to achieve strategic goals on the basis of existing production and resource capabilities of the enterprise. The essential characteristics of the main directions of marketing products policy are revealed and their realization tools are defined. It is offered in the directions determining of marketing products policy to take into account the factors of the external and internal environment, defining the goals and objectives of its implementation. The factors consideration of influence is a prerequisite for the product policy formation because only a thorough and comprehensive study of the external and internal environment of a company is the foundation for creating the effective marketing product policy and achieving goals. As the increase in the products competitiveness of the domestic industrial enterprises is associated with the formation and implementation of the effective product policy in this case, the choice and justification of its directions in the system of the enterprise marketing management is one of the mechanisms for their stable development and strengthening of positions in the international market which turn also requires an appropriate scientific and methodological justification.

Keywords: marketing products policy, industrial enterprise, directions of marketing products policy, factors of the external and internal environment.

\begin{tabular}{|c|c|}
\hline проблеми.Сучасні & привернення \\
\hline виробництва, & окреслених \\
\hline няються жорсткою конкурентною & пов'язане 3 формуванням та \\
\hline $\begin{array}{l}\text { ьбою за увагу спо } \\
\text { ами до якості тс }\end{array}$ & ингової \\
\hline оновлення & Аналіз остан \\
\hline$x$ & публікацій.Питання \\
\hline посилення & концептуальних \\
\hline $\mathrm{HO}$ & рної полі \\
\hline іння & 2 \\
\hline ак & i 3 \\
\hline изначення & Л. В. Балабанова [2], Б. Бе \\
\hline основних & D. $\mathrm{Be}$ \\
\hline товарної & А. В. Войчак [6], С. С. Гаркавенко \\
\hline иємства 3 ме & [8], О. В. Ляхта [9 \\
\hline вачів & \\
\hline 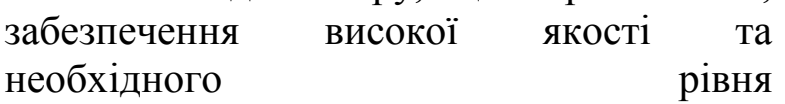 & $\begin{array}{l}\text { агу р } \\
\text { о }[1\end{array}$ \\
\hline урентоспро & C. B \\
\hline & \\
\hline
\end{tabular}

Вісник економіки транспорту і промисловості № 66, 2019 
присвячено вивченню проблеми обгрунтування напрямів та принципів реалізації ефективної маркетингової товарної політики

Виділення невирішених частин загальної проблеми. Проте незважаючи на велику кількість досліджень і наукових розробок в даному напрямку, недостатньо опрацьованим залишається питання розуміння сутності, напрямів та основних завдань маркетингової товарної політики підприємства, що на думку автора, дозволить вітчизняним підприємствам досягти успіху на внутрішньому ринку та забезпечить формування ефективної стратегії виходу на міжнародний ринок.

Метою статті єдослідження сутності, напрямів та основних завдань маркетингової товарної політики вітчизняних промислових підприємства та розробка пропозицій щодо іiї удосконалення в умовах посилення конкуренції та негативного впливу факторів зовнішнього та внутрішнього середовища.

\section{Виклад основного матеріалу} дослідження. Вітчизняні промислові підприємства значно програють зарубіжним компаніям головним чином через недосконалу маркетингову політику, що стримує економічний розвиток вітчизняної промисловості, ускладнює іiі інтеграцію до міжнародного простору. У зв'язку з цим систематизація підходів до розуміння сутності та поняття маркетингової товарної політики підприємства дозволяє обгрунтувати іiі роль у комплексі маркетингу підприємства, виділити основні напрямки тазавдання, які вирішуються в ході іiі реалізації.Ключовим та визначальним елементом як базового, так і розширеного комплексу маркетингу будь-якого підприємства виступає продукт. Маркетингова товарна політика, в свою чергу, являє собою практичну реалізацію даного елементу комплексу маркетингу.Саме тому товарну політику прийнято вважати «ядром маркетингових рішень», так як саме на іії основі будується уся подальша маркетингова діяльність підприємства: формується цінова політика, збутова політика, політика просування тощо. Підходи вітчизняних авторів щодо визначення маркетингової товарної політики та іiі сутнісне наповнення наведено в табл.1.

Таблиия 1

Аналіз існуючих підходів до визначення поняття«товарна політика»

\begin{tabular}{|l|l|l|}
\hline \multicolumn{1}{|c|}{ Автор, } \\
джерело
\end{tabular}

Вісник економіки транспорту і промисловості № 66, 2019 
Продовження табл.1

\begin{tabular}{|c|c|}
\hline 1 & 2 \\
\hline $\begin{array}{l}\text { В.Я Кардаш, } \\
\text { [12] }\end{array}$ & Сукупність засобів впливу на споживачів за допомогою товару \\
\hline $\begin{array}{l}\text { Е В. } \\
\text { Крикавський, } \\
\text { [14] }\end{array}$ & $\begin{array}{l}\text { Певний набір заходів підприємства, що спрямований на розроблення нового } \\
\text { товару та впровадження його на ринок, а також дослідження окремих } \\
\text { компонентів, що забезпечують цей процес }\end{array}$ \\
\hline $\begin{array}{l}\text { О.Ф. Оснач, } \\
{[15]}\end{array}$ & $\begin{array}{l}\text { Визначений курс дій товаровиробника щодо формування товарного } \\
\text { асортименту; його управління; забезпечення конкурентоспроможності товарів } \\
\text { на необхідному рівні; знаходження для товарів цільових сегментів ринку; } \\
\text { розробки і здійснення стратегії упаковки, маркування, сервісного } \\
\text { обслуговування товару; модифікації й модернізації товару і подовження тим } \\
\text { самим життєвого циклу товарів (ЖЦТ) і меж використання товару }\end{array}$ \\
\hline $\begin{array}{l}\text { Н.Б. Ткаче } \\
\text { [16] }\end{array}$ & $\begin{array}{l}\text { Системадій підприємства для визначення місця товару на ринку, задоволення } \\
\text { конкретного потенційного споживача товарами, широких можливостей їх } \\
\text { вибору }\end{array}$ \\
\hline $\begin{array}{l}\text { Г.О. } \\
\text { Холодний, } \\
{[17]}\end{array}$ & $\begin{array}{l}\text { Обгрунтований алгоритм дій, що передбачає визначення виробничої } \\
\text { програми підприємства } 3 \text { урахуванням інтересів споживачів, рівня } \\
\text { впливу конкурентів, виробничих та інших ресурсних можливостей } \\
\text { підприємства, а також стадії життєвого циклу продукту }\end{array}$ \\
\hline \multicolumn{2}{|c|}{$\begin{array}{l}\text { Маркетингова товарна політика - це комплекс дій підприємства, що направлений на } \\
\text { формування та управління конкурентоспроможним асортиментом товарів, за умов } \\
\text { ефективного використання існуючих можливостей } 3 \text { метою задоволення потреб } \\
\text { споживачів та отримання компанією прибутку. }\end{array}$} \\
\hline
\end{tabular}

Проаналізувавши та узагальнивши усі наведенні варіанти можна визначити маркетингову товарну політику як комплекс дій підприємства, що направлений на формуваннята управлінняконкурентоспроможним асортиментом товарів, за умов ефективного використання існуючих можливостей $з$ метою задоволення потреб споживачів та отримання компанією прибутку. Також, виходячи 3 визначень, варто зазначити, що товарна політика тісно пов'язана 3 виробничими та ресурсними можливостями підприємства та обов'язково повинна їх враховувати.

Головна мета ефективної маркетингової товарної політики створення товару, що має визначені конкурентні переваги, максимально повно задовольняе потреби ринку таприноситьприбуток підприємству.До основних цілеймаркетингової товарної політики відносяться:максимальне задоволення потреб споживачів;зниження витрат на виробництво i маркетинг;збільшення рівня товарообігу;збільшення частки ринку підприємства;забезпечення прибутку компанії;підвищення іміджу товару та підприємства в цілому [2].Втілення даних цілей та реалізація головної мети маркетингової товарної політика здійснюється шляхом виконання наступних завдань:

раціональне використання ресурсів підприємства - при плануванні товарної політики врахування ресурсного потенціалу та виробничих можливостей підприємства;

формування товарного асортименту 3 урахуванням бажаного рівня прибутку розрахунок та планування рентабельності продукції, i подальша розробка асортименту, який здатен забезпечити досягнення необхідного рівня прибутку;

випуск нових товарів та управління існуючимиз урахуванням потреб ринку регулярне дослідження ринкового становища передбачає актуалізацію товарів, що виробляються, розробку та 
випуск нової продукції, а також елімінацію застарілої;

управління життевим циклом товарів - напряму пов'язане з управлінням товарами. Передбачає керування товарами, в залежності від того, на якому етапі життєвого циклу вони знаходяться; управління якістю конкурентоспроможністю товарів забезпечення відповідного рівня якості продукції та формування іiі конкурентних переваг;

прийняття рішень щодо пакування та маркування товарів - вибір оптимального пакування, контроль відповідності маркування тощо; прийнятяя рішень щодо використання марок - визначення необхідності використання товарних знаків, марочних знаків, марочних назв та ін., участь в у управлінні правовимиаспектами використання марок; забезпечення

обслуговування товарів - організація сервісного обслуговування товарів [7].

3 огляду на завдання, що вирішує маркетингова товарна політика, основними іï напрямки слід вважати наступні (рис. 1).Управління асортиментом товарів втілюється на практиці у вигляді асортиментної політики підприємства та являє собою комплекс заходів, що направлені на його оптимізацію. Оптимальним асортиментом вважається такий, до складу якого входять товари, що знаходяться на різних стадіях життєвого циклу. При формуванні товарного асортименту одним із ключових завдань $є$ досягнення балансу між потребами споживачів та виробничими можливостями компанії [4].Процес управління товаром як напрям товарної політики пов'язаний 3 управлінням асортиментною політикою та в певній мірі виступає їі частиною.

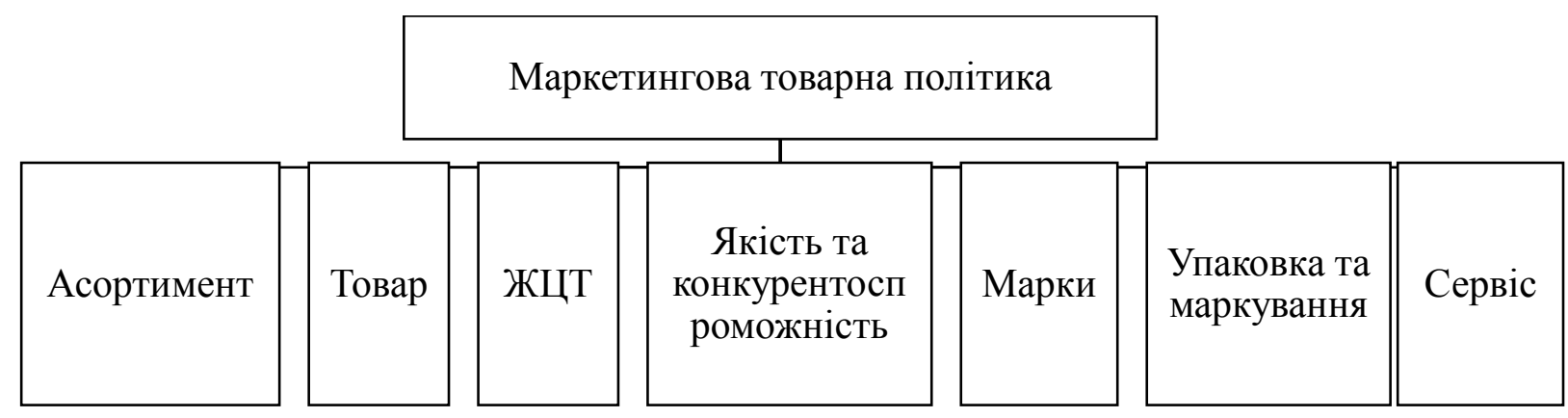

Рис. 1 Напрями маркетингової товарної політики

В залежності від структури асортименту, етапу життєвого циклу товару, його положення на ринку та цілей, які переслідує підприємство, управління товаром може здійснюватися за трьома основними напрямками: розробка нового товару, модифікація існуючого товару, елімінування товару. Таким чином, управління продуктом та управляння асортиментом - це два пов'язані, взаємозалежні структурні складові товарної політики.Також 3 управлінням асортиментом та продуктовим менеджментом тісно пов'язаний наступний напрям товарної політики управління життєвим циклом товару(рис. 2).

Управління життєвим циклом передбачає продовження чи скорочення всього циклу, або його окремих етапів, шляхом внесення змін у товарну, збутову, цінову, комунікаційну стратегії [13; 15].В залежності від того, на якому етапі ЖЦТ знаходиться товар, визначається комплекс задач, який направлений на досягнення конкретної мети, що відповідає поточному етапу. 


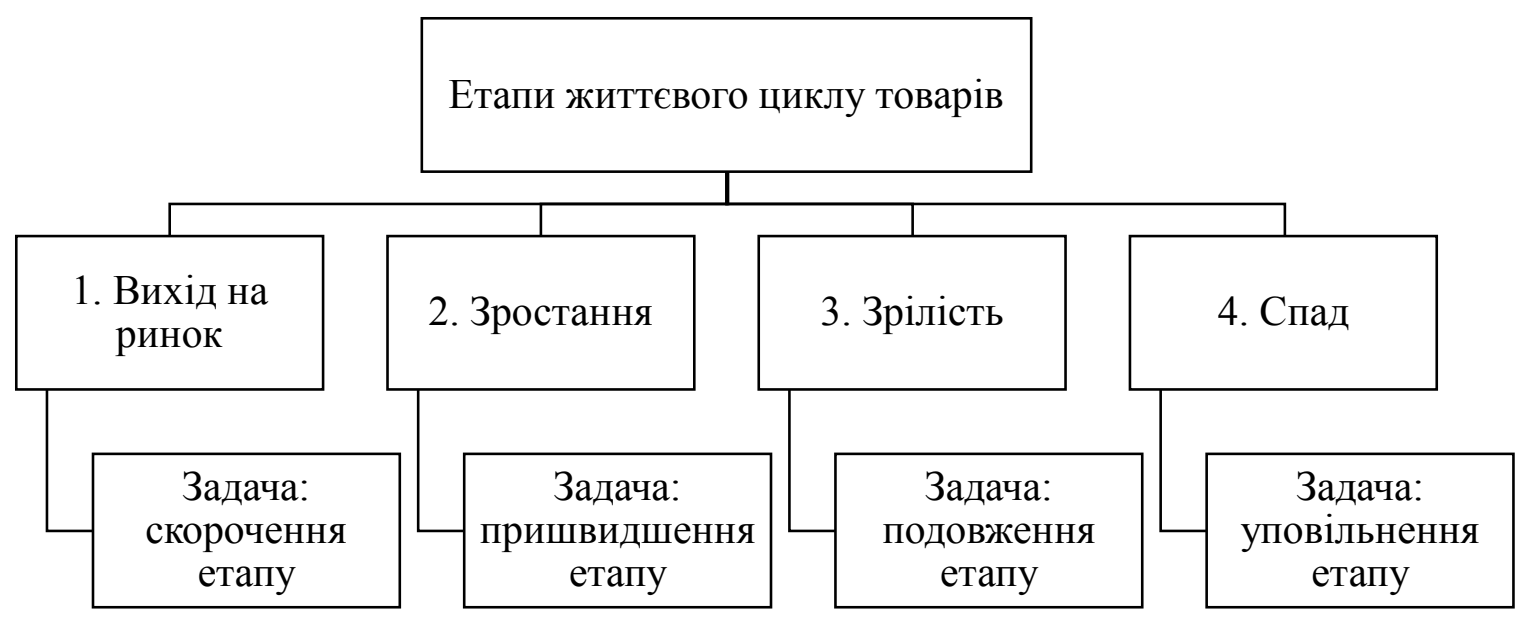

Рис. 2 Задачі товарної політики на етапах життєвого циклу товару

Наступний напрям маркетингової товарної політики - прийняття рішення стосовно якості та конкурентоспроможності товару. В умовах сучасного ринку, який характеризується високим рівнем конкуренції, цей аспект відіграє дуже важливу роль. Забезпечення відповідного рівня якості та формування конкурентних переваг виступають одними 3 головних умов успіху товару на ринку $[1 ; 7]$.

Прийняття рішень стосовно використання марок (марочних назв, знаків, тощо) та вирішення питань, які пов'язані з цим, також виступають одним iз напрямів маркетингової товарної політики.

Також до елементів товарної політики промислового підприємства входить управління упаковкою продукції та маркуванням. Вдала упаковка здатна вигідно презентувати товар, привернути увагу споживача та підштовхнути його до покупки, а відповідне до законодавства, маркування $є$ необхідною складовою будьякої упаковки [11; 17].

Сервіс - це надання покупцям комплексу послуг для забезпечення ефективного використання купленого товару протягом усього його експлуатаційного періоду [7]. Передпродажний сервіс відбувається до моменту придбання товару та полягає у підготовці товару до продажу, а також його обслуговуванні з метою покращення подальшого використання споживачем [3, c. 207].До після продажного сервісу належить гарантійне та післягарантійне обслуговування. Гарантійне обслуговування здійснюється в рамках документального поручительства (гарантіiі) фірми-виробника товару за виконання нею в гарантійний термін зобов'язань щодо обслуговування покупців, які придбали цей товар [7].Післягарантійний сервіс - передбачає перевірку справності, проведення ремонту, постачання запасних частин і т. п. після закінчення гарантійного терміну за додаткову оплату [7].Сервіс є одним із способів, формування конкурентних переваг підприємства та його продукції. Надання сервісних послуг із обслуговування товарної продукції також належить до напрямів маркетингової товарної політики.Гармонійне поєднання усіх цих напрямів та ефективна їх реалізація відповідно до специфіки, умов, можливостей та цілей промислового підприємства дозволяють сформувати ефективну маркетингову товарну політику фірми.

При цьому, варто зазначити, що існує ряд умов, яких необхідно дотримуватись при формуванні маркетингової товарної політики 
підприємства:чітке визначення цілей виробництва та збуту;орієнтація на наявну виробничо-збутову стратегію підприємства;глибоке розуміння вимог та умов функціонування на обраному ринку;реальне визначення виробничих, науково-технічних та інших можливостей і ресурсів підприємства [12].

Також варто зазначити, що на формування маркетингової товарної політики значний вплив чинять зовнішне та внутрішнє середовище підприємства (рис. 3). Залежно від стану та сфери діяльності підприємство може віддавати перевагу тому чи іншому середовищу, фактори якого, відповідно чинитимуть більший вплив на розробку маркетингової товарної політики та іiї подальшу реалізацію. Врахування факторів впливу $\epsilon$ обов'язковою умовою при формуванні товарної політики, адже у зворотному випадку вона може не ефективною наобраному підприємстві.У зв'язку з цим, розробці маркетингової товарної політики передує глибокий всеохоплюючий аналіз підприємства, ринку на якому воно здійснює свою діяльність, положення фірми на цьому ринку, досліджується специфіка продукту, формується портрет споживача тощо. Грунтовне та комплексне дослідження як зовнішнього то внутрішнього середовища фірми $\epsilon$ фундаментом створення ефективної маркетингової товарної політики (рис. 4).

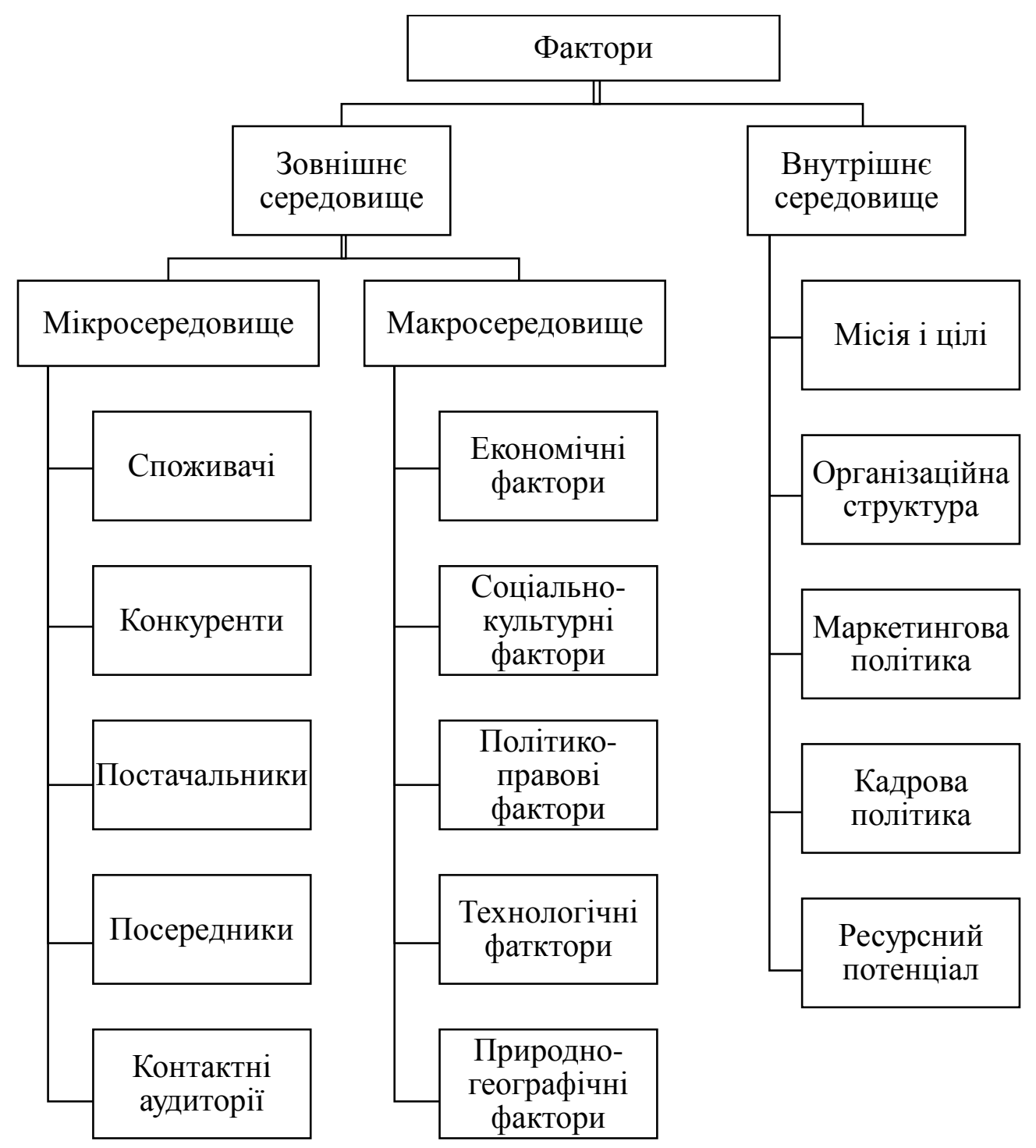

Рис. 3Фактори формування маркетингової товарної політики 


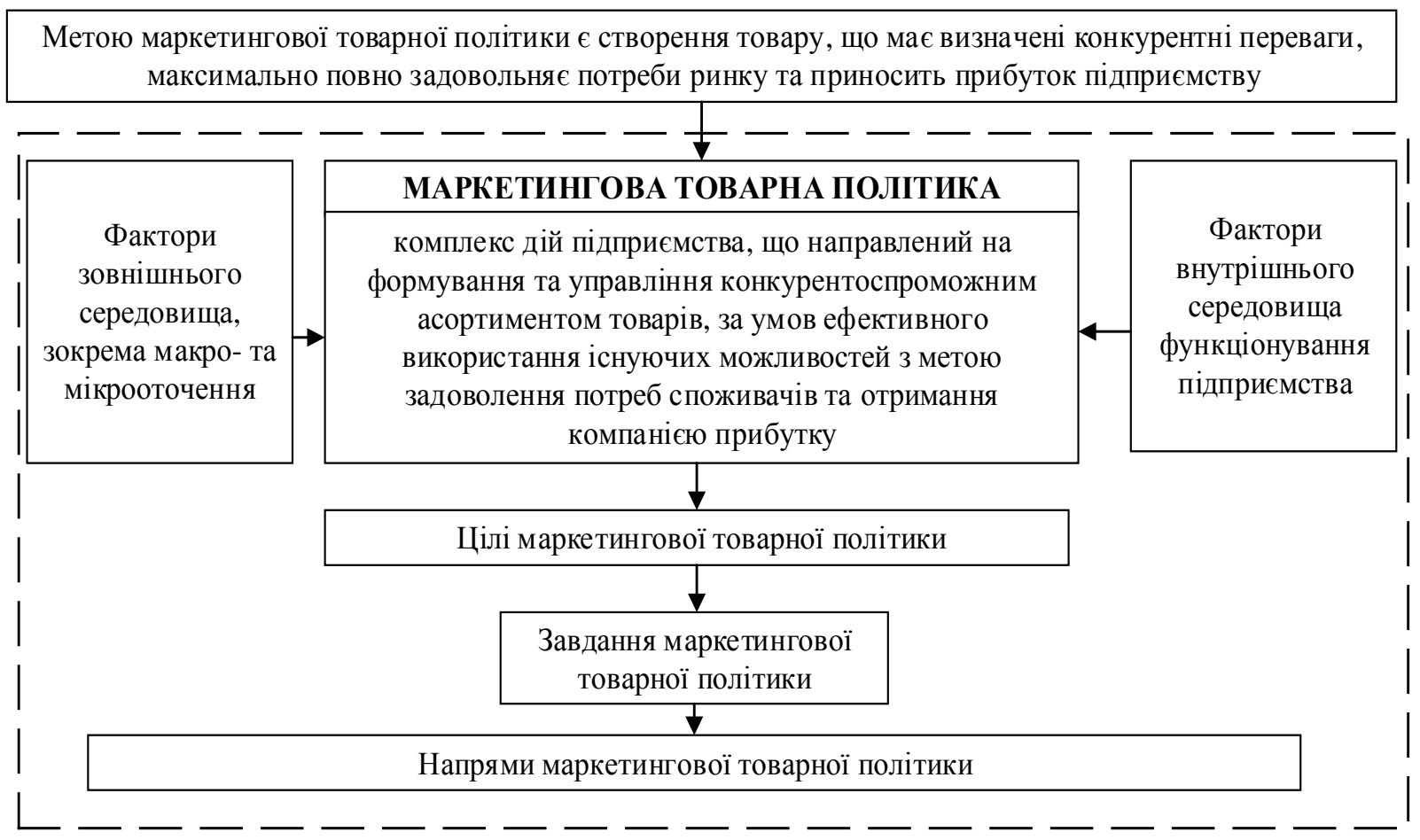

Рис. 4 Теоретичний базис формування ефективної маркетингової політики промислового підприємства

Висновок. Маркетингова товарна політика промислового підприємства представляє собою комплекс дій підприємства, що спрямований на формування та управління конкурентоспроможним асортиментом товарів, за умов ефективного використання існуючих можливостей 3 метою задоволення потреб споживачів та отримання компанією прибутку.Товарна політика виступає «ядром» маркетингового комплексу 4P.

Усі елементи комплексу маркетингмікс напряму залежать від специфіки товарної політики та піi характеристик.Визначальними цілями маркетингової товарної політики виступають максимальне задоволення потреб споживачів та забезпечення прибутків підприємству, на якому вона реалізується.Здійснення товарної політики промислового підприємства відбувається за декількома напрямками, основними 3 яких виступають управління асортиментом та управління товарами, їх якість та конкурентоспроможністю.
Таким чином, в результаті проведеного дослідження сформовано теоретичний базис ефективної маркетингової політики промислового підприємства, зокрема, визначено сутнісне розуміння поняття «маркетингова товарна політика», запропоновано при визначенні напрямів товарної політики враховувати фактори зовнішнього та внутрішнього середовища, що визначають цілі та завдання ii реалізації. Оскільки підвищення конкурентоздатності продукції вітчизняних промислових підприємств науковцями пов'язується із формуванням та реалізацією ефективної товарноїполітики, то в даному випадку, вибір та обгрунтування ऑii напрямів в системі маркетингового управління підприємством виступає як один 3 механізмів стабільного їх розвитку та посилення позицій на міжнародному ринку, що, в свою чергу, також потребує відповідного науково-методичного обгрунтування. 
ПЕРЕЛІК ВИКОРИСТАНИХ ДЖЕРЕЛ

1. Anwar A. Impact of brand image, trust and affect on consumer brand extension attitude: the mediating role of brand loyalty / Anwar A., Gulzar A., Sohail F., Akram, S. // International Journal of Economics and Management Sciences. 2011. -№. 5. - P. 73-79.

2. Балабанова

Л.

B.

Маркетингова товарна політика в системі менеджменту підприємства : навчальний посібник / Л. В. Балабанова, О. А. Бриндіна. - Донецьк: ДонДУЕТ, 2006. 262 c.

3. Берман Б. Розничная торговля: стратегический подход / Б. Берман, Дж. Эванс; пер. с англ. - М., 2003. $-1183 \mathrm{c}$.

4. Бутенко Н. В. Концепція сталого економічного розвитку вітчизняної промисловості / Н. В. Бутенко // Вісник Чернівецького торговельноекономічного інституту. - Економічні науки. - 2011. - Вип. III (43). - С. 15-25.

5. Вершигора Є. Ю. Маркетингова товарна політика. Навчальний посібник для студентів ВНЗ. Хмельниц. екон. ун-т. Тернопіль, Астон, 2015. 407 c.

6. Войчак А. В. Дослідження сучасних концепцій маркетингу та маркетингового менеджменту / А. В. Войчак, В. М. Шумейко // Маркетинг в Україні. - 2009. - № 4. - С. 52-55.

7. Гаркавенко С. С. Маркетинг [Текст] : підручник / С. С. Гаркавенко. - 7е видання. - К. : Лібра, 2010. - 720 с.

8. Джон С. Окленд Всеобщее управление качеством. Маркетинг. Под ред. М.Бейкера. СПб, Питер, 2002. С.941966.

9. Ляхта О. В. Вплив життєвого циклу товару на вибір маркетингової стратегії / О. В. Ляхта // Економічний вісник Донбасу: Науковий журнал. - № 2 (20). - 2010. - С. 152-154. 281.
10. John Burnett. Advertising: Principles and Practice (6th Edition) / John Burnett, William D. Wells, John Burnett, Sandra Moriarty: Prentice Hall, 2002. - 736 c.

11. Ілляшенко С. М. Аналіз задоволеності споживачів та іï впливу на результативність діяльності промислового підприємства / С. М. Ілляшенко, I. В. Меркун // Економіка: реалії часу. 2018. - № 3. - C. 5-14.

12. Кардаш В. Я. Товарна інноваційна політика : підручник / В. Я. Кардаш, I. А. Павленко, О. К. Шафалюк. - К. : КНЕУ, 2002. -266 c.

13. Котлер Ф. Основы маркетинга. Краткий курс. Классический учебник. М., Вильямс, 2008. 641 с.
14
Крикавський
C. B.

Партнерські відносини на ринку В2В та B2C [монографія] /Є. В. Крикавський, I. Петецький, Я. Циран, 3. Люльчак // Львів: Видавництво Львівської політехніки, 2015. - 232c.

15. Оснач О. Ф. Промисловий маркетинг: підручник / О. Ф. Оснач, В. П. Пилипчук, Л. П. Коваленко. - Київ: Центр учбової літератури, 2009. - 365 с.
Ткаченко
$\mathrm{H}$.
Б.

16.

Маркетингова товарна політика. Навч. посібник. / Н. Б. Ткаченко. - Київ, КДТЕУ, 2000.- 149 c.

17. Розвиток управління маркетингом на підприємствах : монографія / Холодний Г. О., Шумська Г. М. - Харків : Вид. ХНЕУ, 2010. - 256 с.

\section{REFERENCES}

1. Anwar A. Impact of brand image, trust and affect on consumer brand extension attitude: the mediating role of brand loyalty / Anwar A., Gulzar A., Sohail F., Akram, S. // International Journal of Economics and Management Sciences. 2011. - №. 5. - P. 73-79.

2. Balabanova L. V. Markety`ngova tovarna polity`ka v sy`stemi menedzhmentu pidpry`yemstva 
navchal`ny`j posibny`k / L. V. Balabanova, O. A. Bry`ndina. - Donecz k: DonDUET, 2006. $-262 \mathrm{~s}$.

3. Berman B. Roznichnaya torgovlya: strategicheskiy podkhod / B. Berman, Dzh. Evans; per. s angl. - M., 2003. $-1183 \mathrm{~s}$.

4. Butenko N. V. Koncepciya stalogo ekonomichnogo rozvy`tku vitchy`znyanoyi promy`slovosti / N. V. Butenko // Visny`k Chernivecz`kogo torgovel 'no-ekonomichnogo insty`tutu. Ekonomichni nauky`. - 2011. - Vy`p. III (43). - C. 15-25.

5. Vershy`gora Ye. Yu. Markety`ngova tovarna polity`ka. Navchal`ny`j posibny`k dlya studentiv VNZ. Xmel`ny`cz. ekon. un-t. Ternopil`, Aston, 2015. $407 \mathrm{~s}$.

6. Vojchak A. V. Doslidzhennya suchasny`x koncepcij markety`ngu ta markety`ngovogo menedzhmentu / A. V. Vojchak, V. M. Shumejko // Markety`ng V Ukrayini. - 2009. - \# 4. - S. 52-55.

7. Garkavenko S. S. Markety`ng [Tekst] : pidruchny`k / S. S. Garkavenko. - 7e vy`dannya. - K. : Libra, 2010. - 720 s.

8. Dzhon S. Oklend Vseobshchee upravlenie kachestvom. Marketing. Pod red. M.Beykera. SPb, Piter, 2002. S.941-966.

9. Lyaxta O. V. Vply`v zhy`ttyevogo cy`klu tovaru na vy`bir markety`ngovoyi strategiyi / O. V. Lyaxta // Ekonomichny`j visny`k Donbasu: Naukovy`j zhurnal. - \# 2 (20). - 2010. - S. 152-154. 281.
10. John Burnett. Advertising: Principles and Practice (6th Edition) / John Burnett, William D. Wells, John Burnett, Sandra Moriarty: Prentice Hall, 2002. - 736 c.

11. Illyashenko S. M. Analiz zadovolenosti spozhy`vachiv ta yiyi vply`vu na rezul'taty`vnist diyal’nosti promy`slovogo pidpry`yemstva / S. M. Illyashenko, I. V. Merkun // Ekonomika: realiyi chasu. - 2018. - \# 3. - S. 5-14.

12. Kardash V. Ya. Tovarna innovacijna polity`ka : pidruchny`k / V. Ya. Kardash, I. A. Pavlenko, O. K. Shafalyuk. K. : KNEU, 2002. $-266 \mathrm{~s}$.

13. Kotler F. Osnovy marketinga. Kratkiy kurs. Klassicheskiy uchebnik. M., Vil'yams, 2008. $641 \mathrm{c}$.

14. Kry`kavs`ky`j Ye. V. Partners`ki vidnosy`ny` na ry`nku V2V ta V2S [monografiya] /Ye. V. Kry`kavs`ky`j, I. Petecz`ky`j, Ya. Cy`ran, Z. Lyul`chak // L`viv: Vy`davny`cztvo L`vivs`koyi politexniky`, 2015. - 232s.

15. Osnach O. F. Promy`slovy`j markety`ng: pidruchny`k / O. F. Osnach, V. P. Py`ly`pchuk, L. P. Kovalenko. - Ky`yiv: Centr uchbovoyi literatury`, 2009. - 365 s.

16. Tkachenko N. B. Markety`ngova tovarna polity`ka. Navch. posibny`k. / N. B. Tkachenko. - Ky`yiv, KDTEU, 2000.- 149 s.

17. Rozvy`tok upravlinnya markety`ngom na pidpry`yemstvax : monografiya / Xolodny`j G. O., Shums`ka G. M. - Xarkiv : Vy`d. XNEU, 2010. - 256 s. 